\title{
Pengaruh Model Pembelajaran Teams Games Tournament Menggunakan Sandi Semaphore Pramuka Terhadap Kemampuan Pemecahan Masalah Matematis Ditinjau dari Tipe Kepribadian Siswa
}

\author{
Siti Nurfajriah ${ }^{1}$, Netriwati ${ }^{2}$, Rany Widyastuti ${ }^{3}$ \\ 1, 2, 3 Program Studi Pendidikan Matematika, Universitas Islam Negeri Raden Intan Lampung \\ Jl. Letkol H. Endro Suratmin, Sukarame, Bandar Lampung, Lampung, Indonesia \\ sitinurfajriah.sn45@gmail.com
}

\begin{abstract}
The aims of this study were (1) to determine the effect of TGT (Teams Games Tournament) learning model using the scout semaphore code on students' mathematical problem-solving abilities. (2) To determine the effect of students' personality types on students' mathematical problem-solving abilities. (3) To find out the interaction between the learning model and the student's personality type on students' mathematical problem-solving abilities. This research is a Quasy experimental design research. Random sampling technique. The technique of collecting data is through tests of mathematical problem-solving abilities and personality type questionnaires. The analytical technique used is analysis of variance in two unequal cell paths. According to the results of research and analysis of variance analysis of two unequal cell paths, it was found that: (1) There was an effect of the TGT (Teams Games Tournament) learning model using the scout semaphore code on students' mathematical problem-solving abilities. (2) There is no influence of students' personality type on students' mathematical problem-solving abilities. (3) There is no interaction between the learning model and the student's personality type on students' mathematical problem-solving abilities.
\end{abstract}

Keywords: Teams Games Tournament (TGT) Learning Model, Scout Semaphore Code, Mathematical ProblemSolving Ability, Personality Type.

Abstrak
Tujuan penelitian ini ialah (1) Untuk mengetahui pengaruh model pembelajaran TGT (Teams Games Tournament) menggunakan sandi semaphore pramuka terhadap kemampuan pemecahan masalah matematis siswa. (2) Untuk mengetahui pengaruh tipe kepribadian siswa terhadap kemampuan pemecahan masalah matematis siswa. (3) Untuk mengetahui interaksi antara model pembelajaran dengan tipe kepribadian siswa terhadap kemampuan pemecahan masalah matematis siswa. Penelitian ini merupakan penelitian Quasy experiment research. Teknik pengambilan sampel secara acak. Teknik pengumpulan data melalui tes kemampuan pemecahan masalah matematis dan angket tipe kepribadian. Teknik analisis yang digunakan analisis variansi dua jalan sel tak sama. Menurut hasil penelitian dan perhitungan uji analisis variansi dua jalan sel tak sama didapatkan bahwa: (1) Terdapat pengaruh model pembelajaran TGT (Teams Games Tournament) menggunakan sandi semaphore pramuka terhadap kemampuan pemecahan masalah matematis siswa. (2) Tidak terdapat pengaruh tipe kepribadian siswa terhadap kemampuan pemecahan masalah matematis siswa. (3) Tidak terdapat interaksi antara model pembelajaran dengan tipe kepribadian siswa terhadap kemampuan pemecahan masalah matematis siswa.

Kata kunci: Model Pembelajaran Teams Games Tournament (TGT), Sandi Semaphore Pramuka, Kemampuan Pemecahan Masalah Matematis, Tipe Kepribadian

Copyright (c) 2021 Siti Nurfajriah, Netriwati, Rany Widyastuti

$\triangle$ Corresponding author: Siti Nurfajriah

Email Address: sitinurfajriah.sn45@gmail.com (Jl. Letkol H. Endro Suratmin, Sukarame, Bandar Lampung)

Received 05 July 2021, Accepted 15 July 2021, Published 21 October 2021

\section{PENDAHULUAN}

Di zaman sekarang, ilmu pengetahuan dan teknologi mengalami perkembangan yang sangat cepat sehingga mengharuskan manusia agar mempunyai kemampuan dan keahlian berdasarkan tuntutan zaman maupun kebutuhan. Pendidikan menjadi sesuatu yang sangat penting dalam upaya mengembangkan kualitas SDM. Pendidikan lebih dari sekedar pengajaran, karena dalam kenyataannya, pendidikan merupakan suatu proses dimana bangsa atau negara membina dan mengembangkan 
Pengaruh Model Pembelajaran Teams Games Tournament Menggunakan Sandi Semaphore Pramuka Terhadap Kemampuan Pemecahan Masalah Matematis Ditinjau dari Tipe Kepribadian Siswa, Siti Nurfajriah, Netriwati, Rany Widyastuti

kesadaran diri diantara individu-individu (Nurjanah, 2019). Beberapa pakar pendidikan di Indonesia sudah berupaya mengembangkan pendidikan menggunakan sejumlah upaya, yakni memperbaiki sistem pendidikan dan menyempurnakan materi pelajaran. Salah satu kemampuan yang diharapkan pada siswa dalam pembelajaran matematika yakni kemampuan memecahkan permasalahan (Kementerian Pendidikan dan Kebudayaan, 2006). Dengan demikian, sangat pentingnya kemampuan tersebut pada kurikulum matematika. Keahlian dalam memecahkan permasalahan matematika tentunya tidak mudah, tidak hanya bisa menjawab persoalan yang diberikan saja, tapi peserta didik diharuskan supaya mempunyai kompetensi dalam menyelesaikan permasalahan, menguasai permasalahan, merumuskan perencanaan pemecahan, memecahkan permasalahan berdasarkan rencana, dan melakukan pemeriksaan ulang terhadap jawaban yang sudah didapatkan. Kompetensi siswa untuk menyelesaikan permasalahan matematika sangatlah berdampak pada hasil pembelajaran siswa ke depannya.

Peneliti sebelumnya melaksanakan pra penelitian sebelum melakukan penelitian, agar mengetahui seperti apa permasalahan yang ada. Sesuai dengan hasil pra penelitian yang dilaksanakan maka dipahami nilai matematika di SMP Al-Huda Jati Agung Lampung Selatan kurang maksimal. Sebagaimana yang terlihat pada nilai ulangan harian dengan hasil yang belum memuaskan. Kemampuan pemecahan masalah matematis siswa juga masih rendah, hal ini disebabkan karena siswa belum memahami soal yang diberikan oleh guru sehingga siswa masih kesulitan dalam menyeselaikan masalah yang diberikan. Siswa masih mengerjakan soal secara langsung tanpa menuliskan dahulu informasi apa saja yang diketahui dalam soal, pertanyaan apa yang dimaksud dalam soal dan rumus apa yang digunakan untuk menyelesaian soal. Hal lain juga terlihat bahwasanya siswa langsung menjawab pertanyaan tanpa mengulangi kembali langkah-langkah penyelesaian soal sudah tepat atau belum.

Belum optimalnya kemampuan pemecahan masalah matematis siswa disebabkan oleh salah satunya yaitu model pembelajaran yang dipergunakan oleh guru. Model pembelajaran yang digunakan lebih mengacu pada pembelajaran konvensional, guru hanya memberikan materi dan penugasan, tanpa melakukan timbal balik berupa langkah-langkah pengerjaan soal yang benar. Metode yang digunakan dalam pembelajaran pun masih menggunakan metode ceramah sehingga guru tidak melibatkan siswa secara langsung dalam proses pembelajaran.

Sesuai dengan permasalaan yang sudah dipaparkan tersebut, dengan demikian perlu adanya pembaharuan pada kegiatan belajar mengajar yang bisa meningkatkan hasil belajar peserta didik sebagai usaha meningkatkan kemampuan menyelesaikan persoalan matematika. Berhubungan terhadap penelitian yang dilaksanakan, maka diharapkan ada peningkatan dalam bentuk pembaharuan pada kegiatan belajar mengajar matematika. Pada model pembelajaran pada matematika yang bisa diterapkan yakni model pembelajaran kooperatif. Terdapat beberapa tipe dalam pembelajaran kooperatif, salah satunya tipe TGT (Teams Games Tournament). Model pembelajaran kooperatif tipe TGT merupakan salah satu tipe dari model pembelajaran kooperatif yang mudah diterapkan karena melibatkan aktivitas seluruh siswa tanpa harus ada perbedaan status, melibatkan peran siswa sebagai tutor sebaya, dan mengandung unsur permainan serta penguatan (reinforcement). Berdasarkan hasil wawancara dengan 
Ibu Anisa Fitri, S.Pd., yang mengatakan bahwa guru kesulitan mengetahui tingkat keberhasilan siswa dan kemampuan pemecahan masalah matematis siswa yang disebabkan karena tipe kepribadian siswa berbeda-beda, sehingga peneliti tertarik untuk meneliti pengaruh tipe kepribadian terhadap kemampuan pemecahan masalah matematis.

Menurut penelitian terdahulu ada juga yang menyatakan model pembelajaran TGT (Teams Games Tournament) Modifikasi Metode Gasing mempunyai pengaruh terhadap meningkatkan kemampuan pemecahan masalah matematis siswa (Delima, 2019). Dengan demikian, peneliti tertarik ingin memodifikasi model pembelajaran kooperatif tipe TGT tersebut dengan bantuan media pembelajaran Sandi Semaphore Pramuka. Sandi Semaphore adalah kode yang biasanya digunakan oleh anggota pramuka dalam suatu permainan dan menggunakan bendera sebagai media komunikasinya, lalu bendera tersebut digerakan seperti putaran jarum jam (Sunardi, 2016). Hampir di semua sekolah formal selalu ada kegiatan ekstrakurikuler pramuka, ini merupakan sebuah realita yang tercantum dalam Peraturan Menteri Pendidikan dan Kebudayaan Republik Indonesia Nomor 63 Tahun 2014 tentang Pendidikan Kepramukaan Sebagai Kegiatan Ekstrakurikuler Wajib Pada Pendidikan Dasar dan Pendidikan Menengah. Selain itu juga pramuka merupakan ekstrakulikuler yang banyak diminati oleh siswa di SMP Al-Huda Jati Agung, bahkan SMP Al-Huda Jati Agung merupakan salah satu sekolah terbaik dalam bidang kepramukaan di Lampung Selatan.

Penelitian lain juga menyatakan bahwa model pembelajaran Teams Games Tournament (TGT) berpengaruh dalam meningkatkan kemampuan pemecahan masalah matematika siswa dan self afficacy siswa (Dian Safitri, 2020). Berdasarkan hasil wawancara dengan Ibu Anisa Fitri, S.Pd., yang mengatakan bahwa guru kesulitan mengetahui tingkat keberhasilan siswa dan kemampuan pemecahan masalah matematis siswa yang disebabkan karena tipe kepribadian siswa berbeda-beda, sehingga peneliti tertarik untuk meneliti pengaruh tipe kepribadian terhadap kemampuan pemecahan masalah matematis.

Berdasarkan skala preferensi Keirsey dan Bates menggolongkan tipe kepribadian kedalam empat tipe yaitu kepribadian Guardian, Artisan, Rational, dan Idealist (Sahriai, 2021). Dari penelitian Novitasari dibuktikan siswa dengan tipe kepribadian Guardian, Artisan, Rational, dan Idealist memperoleh hasil belajar yang berbeda. Hal ini artinya siswa dengan tipe kepribadian yang berbedabeda bisa mempengaruhi hasil belajar siswa, sehingga peneliti tertarik untuk menggunakan empat tipe kepribadian menurut skala preferensi Keirsey dan Bates yaitu tipe kepribadian Guardian, Artisan, Rational dan Idealist.

Penelitian ini menggunakan materi garis dan sudut. Alasan peneliti menggunakan materi garis dan sudut adalah karena materi ini memungkinkan peneliti untuk bisa menggunakan media pembelajaran Sandi Semaphore Pramuka. Berdasarkan dengan uraian diatas, maka peneliti tertarik umtuk melakukan penelitian dengan judul "Pengaruh Model Pembelajaran Teams Games Tournament Menggunakan Sandi Semaphore Pramuka Terhadap Kemampuan Pemecahan Masalah Matematis Ditinjau Dari Tipe Kepribadian Siswa". 
Pengaruh Model Pembelajaran Teams Games Tournament Menggunakan Sandi Semaphore Pramuka Terhadap Kemampuan Pemecahan Masalah Matematis Ditinjau dari Tipe Kepribadian Siswa, Siti Nurfajriah, Netriwati, Rany Widyastuti

\section{METODE}

Penelitian ini menggunakan jenis eksperimen yaitu quasy experiment research dimana design ini memiliki kelompok kontrol tetapi tidak berfungsi sepenuhnya untuk mengontrol variabel-variabel luar yang mempengaruhi pelaksanaan eksperimen tersebut (Siregar, 2019). Penelitian ini menggunakan penelitian kuntitatif. Penelitian kuantitatif merupakan penelitian yang dilakukan dengan mengumpulkan data berupa angka. Data yang berupa angka selanjutnya diolah dan dianalisis untuk memperoleh informasi ilmiah (Iswati, 2017).

Pelaksanaan kegiatan pembelajaran penelitian ini menggunakan model pembelajaran TGT (Teams Games Tournament) berbantuan sandi semaphore pramuka, yang selanjutnya sesudah kegiatan pembelajaran tersebut dianalisis bagaimana kemampuan pemecahan masalah matematis. Selain itu, penulis juga akan meneliti faktor luaran yang mempengaruhi kemampuan pemecahan masalah matematis yaitu tentang tipe kepribadian siswa. Rancangan penelitian yang akan digunakan dalam penelitian ini ialah rancangan faktorial $2 \times 4$.

Tabel 1. Rancangan Penelitian

\begin{tabular}{|l|c|c|c|c|}
\hline $\begin{array}{l}\text { Mipe Kepribadian } \\
\text { Model }\end{array}$ & $\begin{array}{c}\text { Guardian } \\
\left(\mathbf{B}_{1}\right)\end{array}$ & $\begin{array}{c}\text { Artisan } \\
\left(\mathbf{B}_{2}\right)\end{array}$ & $\begin{array}{c}\text { Rational } \\
\left(\mathbf{B}_{3}\right)\end{array}$ & $\begin{array}{c}\text { Idealist } \\
\left(\mathbf{B}_{4}\right)\end{array}$ \\
\hline $\begin{array}{l}\text { Model Pembelajaran } \\
\text { Teams Games } \\
\text { Tournament (TGT) } \\
\begin{array}{l}\text { Menggunakan Sandi } \\
\text { Semaphore Pramuka } \\
\text { (A1) }\end{array}\end{array}$ & (A1B1) & (A1B2) & (A1B3) & (A1B4) \\
\hline $\begin{array}{l}\text { Model Pembelajaran } \\
\text { Konvensional (A2) }\end{array}$ & (A2B1) & (A2B2) & (A2B3) & (A2B4) \\
\hline
\end{tabular}

Penelitian ini dilakukan pada bulan April 2021 dengan materi Garis dan Sudut. Populasi pada penelitian ini adalah siswa kelas VII SMP Al-Huda Jati Agung dan sampelnya yakni kelas VII A1 dan VII A3 yang dipilih dengan teknik Claster Random Sampling. Adapun kelas VII A1 merupakan kelas eksperimen yang diajarkan menggunakan model pembelajaran Teams Games Turnament menggunakan sandi semaphore pramuka dan kelas VII A3 sebagai kelas kontrol yang diajarkan dengan model pembelajaran konvensional.

Data dalam penelitian ini adalah data tes kemampuan pemecahan masalah matematis yang dikumpulkan dengan istrumen postest dan angket tipe kepribadian siswa. Sebelum penelitian, instrumen divalidasi terlebih dahulu oleh satu orang ahli instrumen angket dan tiga orang ahli instrumen soal, setelah didapatkan penilaian yang valid dan tidak perlu direvisi lagi maka instrumen dapat digunakan untuk penelitian. Setelah menyiapkan keperluan penelitian kemudian kelas eksperimen diberikan 
perlakuan dengan model pembelajaran Teams Games Turnament menggunakan sandi semaphore pramuka dan kelas kontrol diberikan perlakuan dengan model pembelajaran konvensional, setelah itu kedua kelas diberikan angket tipe kepribadian dan soal posttest pemecahan masalah matematis. Setelah data terkumpul maka data dianalisis dengan menggunakan anova dua jalur sel tak sama dan uji komparasi ganda.

\section{HASIL DAN DISKUSI}

Data angket yang disebar peneliti berdasar pada penggolongan tipe kepribadian masing-masing siswa, seperti tabel berikut:

Tabel 2. Jumlah Siswa Tes Tipe Kepribadian MBTI

\begin{tabular}{|c|c|c|c|c|c|}
\hline \multirow{2}{*}{ Kelas } & \multicolumn{4}{|c|}{ Tipe Kepribadian MBTI } & \multirow{2}{*}{ Jumlah } \\
\cline { 2 - 5 } & Guardian & Artisan & Rational & Idealist & \\
\hline VII A1 & 8 & 11 & 3 & 8 & 30 \\
\hline VII A3 & 11 & 12 & 3 & 4 & 30 \\
\hline
\end{tabular}

Berdasarkan hasil penyebaran angket tipe kepribadian diperoleh kelas VII A1 dengan tipe kepribadian Guardian terdiri 8 siswa, 11 siswa tipe Artisan, 3 siswa tipe Rational, dan 8 siswa tipe Idealist. Kelas VII A3 dengan tipe kepribadian Guardian terdiri 11 siswa, 12 siswa tipe Artisan, 3 siswa tipe Rational, dan 4 siswa tipe Idealist.

Data nilai posttest terlebih dahulu diuji normalitas dan homogenitas sebagai prasyarat untuk uji hipotesis. Uji normalitas dilakukan guna mengetahui apakah sampel berasal dari populasi yang berdistribusi normal atau tidak. Uji normalitas yang digunakan dalam penelitian ini menggunakan uji liliefors dengan taraf signifikansi 5\%. Pengujian normalitas dalam penelitian digunakan untuk menguji normalitas kemampuan pemahaman konsep siswa. Berikut hasil uji normalitas data kemampuan pemahaman konsep dapat dilihat pada tabel berikut.

Tabel 3. Hasil Uji Normalitas Data Kemampuan Pemecahan Masalah Matematis

\begin{tabular}{|c|c|c|c|c|c|}
\hline No. & Kelompok & $\mathbf{N}$ & $\boldsymbol{L}_{\text {hitung }}$ & $\boldsymbol{L}_{\text {tabel }}$ & Keputusan Uji \\
\hline 1 & Eksperimen $\left(\mathrm{A}_{1}\right)$ & 30 & 0,156 & 0,161 & $H_{0}$ diterima \\
\hline 2 & Kontrol $\left(\mathrm{A}_{2}\right)$ & 30 & 0,150 & 0,161 & $H_{0}$ diterima \\
\hline
\end{tabular}

Berdasarkan Tabel 3 menunjukkan kemampuan pemecahan masalah matematis pada kelas eksperimen didapat $L_{\text {hitung }}=0,156$. Untuk sampel sebanyak 30 siswa dan taraf signifikasi $a=0,05$ maka diperoleh $L_{\text {tabel }}=0,161$. Hasil perhitungan tersebut memperlihatkan bahwa $L_{\text {hitung }} \leq L_{\text {tabel }}$, sehingga $H_{0}$ diterima. Pada kelas kontrol didapat $L_{\text {hitung }}=0,150$ dan untuk sampel sebanyak 30 siswadan taraf signifikasi $a=0,05$ maka diperoleh $L_{\text {tabel }}=0,161$. Hasil perhitungan tersebut memperlihatkan bahwa $L_{\text {hitung }} \leq L_{\text {tabel }}$, sehingga $H_{0}$ diterima. Hal ini nenunjukan bahwa data kemampuan pemecahan matematis berdasarkan kelas berditribusi normal. 
Pengaruh Model Pembelajaran Teams Games Tournament Menggunakan Sandi Semaphore Pramuka Terhadap Kemampuan Pemecahan Masalah Matematis Ditinjau dari Tipe Kepribadian Siswa, Siti Nurfajriah, Netriwati, Rany Widyastuti

Tabel 4. Hasil Uji Normalitas Data Kemampuan Pemecahan Masalah Matematis Berdasarkan Tipe

\begin{tabular}{|c|c|r|c|c|c|}
\hline No. & Kelompok & $\mathbf{N}$ & $\boldsymbol{L}_{\text {hitung }}$ & $\boldsymbol{L}_{\text {tabel }}$ & Keputusan Uji \\
\hline 1 & Guardian $\left(\mathrm{B}_{1}\right)$ & 20 & 0,158 & 0,190 & $H_{0}$ diterima \\
\hline 2 & Artisan $\left(\mathrm{B}_{2}\right)$ & 22 & 0,173 & 0,190 & $H_{0}$ diterima \\
\hline 3 & Rational $\left(\mathrm{B}_{3}\right)$ & 6 & 0,208 & 0,319 & $H_{0}$ diterima \\
\hline 4 & Idealist $\left(\mathrm{B}_{4}\right)$ & 12 & 0,206 & 0,242 & $H_{0}$ diterima \\
\hline
\end{tabular}

Berdasarkan Tabel 3, diketahui kemampuan pemecahan masalah matematis berdasarkan tipe kepribadian guardian pada kelas eksperimen dan kelas kontrol didapat $L_{\text {hitung }}=0,158$. Untuk sampel sebanyak 20 siswa dan taraf signifikasi $a=0,05$ maka diperoleh $L_{\text {tabel }}=0,190$. Hasil perhitungan tersebut memperlihatkan bahwa $L_{\text {hitung }} \leq L_{\text {tabel }}$, sehingga $H_{0}$ diterima. Kemampuan pemecahan masalah matematis berdasarkan tipe kepribadian Artisan pada kelas eksperimen dan kelas kontrol didapat $L_{\text {hitung }}=0,173$. Untuk sampel sebanyak 22 siswa dan taraf signifikasi $a=0,05$ maka diperoleh $L_{\text {tabel }}=0,190$. Hasil perhitungan tersebut memperlihatkan bahwa $L_{\text {hitung }} \leq L_{\text {tabel }}$, sehingga $H_{0}$ diterima. Kemampuan pemecahan masalah matematis berdasarkan tipe kepribadian rational pada kelas eksperimen dan kelas kontrol didapat $L_{\text {hitung }}=0,208$. Untuk sampel sebanyak 6 siswa dan taraf signifikasi $a=0,05$ maka diperoleh $L_{\text {tabel }}=0,319$. Hasil perhitungan tersebut memperlihatkan bahwa $L_{\text {hitung }} \leq L_{\text {tabel }}$, sehingga $H_{0}$ diterima. Kemampuan pemecahan masalah matematis berdasarkan tipe kepribadian idealist pada kelas eksperimen dan kelas kontrol didapat $L_{\text {hitung }}=0,206$. Untuk sampel sebanyak 12 siswa dan taraf signifikasi $a=0,05$ maka diperoleh $L_{\text {tabel }}=0,242$. Hasil perhitungan tersebut memperlihatkan bahwa $L_{\text {hitung }} \leq L_{\text {tabel }}$, sehingga $H_{0}$ diterima. Hal ini nenunjukan bahwa data kemampuan pemecahan matematis berdasarkan kelas berditribusi normal.

Uji homogenitas dipakai untuk melihat sama atau tidaknya varians dalam populasi data. Uji homogenitas dalam penelitian ini dilakukan pada data nilai kemampuan pemecahan masalah matematis siswa. Pengujian homogenitas menggunakan metode Barlett. Hasil analisis data kemampuan pemecahan masalah matematis siswa kelas VIIA1 dan VIIA2 yang diterapkan dengan model pembelajaran Teams Games Tournament (TGT) menggunakan sandi semaphore pramuka dan model pembelajaran konvensional adalah sebagai berikut.

Tabel 5. Hasil Uji Homogenitas Kemampuan Pemecahan Masalah Matematis Berdasarkan Kelas

\begin{tabular}{|c|c|c|c|c|}
\hline Kelompok & $\mathbf{N}$ & $\chi_{\text {hitung }}^{\mathbf{2}}$ & $\chi_{\text {tabel }}^{\mathbf{2}}$ & Keputusan Uji \\
\hline Eksperimen & 30 & 0,000 & 3,481 & $H_{0}$ Diterima \\
\hline Kontrol & 30 & 0,00 & \\
\hline
\end{tabular}

Berdasarkan tabel 5 diperoleh $\chi_{\text {hitung }}^{2}=0,000$ dan berdasarkan tabel Chi Kuadrat dngan taraf signifikan $5 \%$ dan $\mathrm{k}-1=2-1=1$ didapat $\chi_{\text {tabel }}^{2}=3,481$. Diketahui bahwa $\chi_{\text {hitung }}^{2}=0,000 \leq$ $\chi_{\text {tabel }}^{2}=3,481$ maka $H_{0}$ diterima dengan demikian sampel berasal dari populasi yang homogen. 
Uji hipotesis dilakukan dengan menganalisis melalui perhitungan anava dua jalan sel tak sama karena masing-masing data kelompok yang berbeda-beda. Hasil uji Anova disajikan pada Tabel 4.10 berikut:

Tabel 6. Rangkuman Analisis Variansi Dua Jalan

\begin{tabular}{|l|c|c|c|c|c|}
\hline Sumber Keragaman & Db & JK & KT & $\boldsymbol{F}_{\text {hitung }}$ & $\boldsymbol{F}_{\text {tabel }}$ \\
\hline Baris (B) & 1 & 510,417 & 510,417 & 13,846 & 4,010 \\
\hline Kolom (K) & 3 & 181,532 & 60,511 & 1,641 & 2,766 \\
\hline Interaksi (I) & 3 & 273,644 & 91,215 & 2,474 & 2,766 \\
\hline Galat (G) & 57 & 3066,850 & 53,804 & & \\
\hline Total & & 3066,850 & & & \\
\hline
\end{tabular}

Berdasarkan tabel 6 perhitungan uji hipotesis variansi dua jalan sel tak sama dapat disimpulkan bahwa:

1. Pada baris kelas diketahui nilai $F_{\text {hitung }}$ sebesar 13,846 dan $F_{\text {tabel }}$ sebesar 4,010 sehingga diperoleh $F_{\text {hitung }}>F_{\text {tabel }}$ maka $\mathrm{H}_{0 \mathrm{~A}}$ ditolak jadi kesimpulannya bahwa terdapat pengaruh model pembelajaran Teams Games Tournament (TGT) menggunakan sandi semaphore pramuka terhadap kemampuan pemecahan masalah matematis siswa.

2. Pada baris kepribadian diketahui nilai $F_{\text {hitung }}$ sebesar 1,125 dan $F_{\text {tabel }}$ sebesar 2,766 sehingga diperoleh $F_{\text {hitung }}<F_{\text {tabel }}$ maka $\mathrm{H}_{0 \mathrm{~B}}$ diterima jadi kesimpulannya bahwa tidak terdapat perbedaan efek tipe kepribadian guardian, artisan, rational, dan idealist siswa terhadap kemampuan pemecahan masalah matematis siswa.

3. Pada kelas tipe kepribadian diketahui nilai $F_{\text {hitung }}$ sebesar 1,695 dan $F_{\text {tabel }}$ sebesar 2,766 sehingga diperoleh $F_{\text {hitung }}<F_{\text {tabel }}$ maka $\mathrm{H}_{0 \mathrm{AB}}$ diterima jadi kesimpulannya bahwa tidak ada interaksi antara model pembelajaran dan tipe kepribadian siswa terhadap kemampuan pemecahan masalah matematis.

Berdasarkan perhitungan analisis variansi dua jalan sel tak sama yang telah dilakukan diperoleh keputusan uji bahwa $\mathrm{H}_{0 \mathrm{~A}}$ ditolak, $\mathrm{H}_{0 \mathrm{~B}}$ diterima dan $\mathrm{H}_{0 \mathrm{AB}}$ diterima. Berdasarkan hal tersebut menunjukan hanya pada variabel baris yang terdapat perbedaan sehingga variabel baris perlu dilakuka uji komparasi ganda dan variabel kolom tidak perlu lagi dilakuka uji komparasi ganda. Variabel baris hanya ada dua yaitu model pembelajaran Teams Games Tournament (TGT) menggunakan sandi semaphore pramuka dan model pembelajaran konvensional oleh karena itu uji komperasi ganda dilakukan hanya untuk melihat perbedaan rata- rata nilai kemampuan pemecahan masalah siswa. Hasil perhitungan dapat dilihat pada tebel berikut:

Tabel 7. Rangkuman Rata-rata dan rataan marginal

\begin{tabular}{|c|c|c|c|c|c|}
\hline \multirow{2}{*}{ Model Pembelajaran } & \multicolumn{4}{|c|}{ Tipe Kepribadian } & \multirow{2}{*}{$\begin{array}{c}\text { Rataan } \\
\text { Marginal }\end{array}$} \\
\hline & Guardian & Artisan & Rational & Idealist & \\
\hline $\begin{array}{l}\text { Model Pembelajaran TGT Menggunakan } \\
\text { Sandi Semaphore Pramuka (A1) }\end{array}$ & 79,89 & 76,3 & 86 & 82,375 & 81,141 \\
\hline
\end{tabular}


Pengaruh Model Pembelajaran Teams Games Tournament Menggunakan Sandi Semaphore Pramuka Terhadap Kemampuan Pemecahan Masalah Matematis Ditinjau dari Tipe Kepribadian Siswa, Siti Nurfajriah, Netriwati, Rany Widyastuti

\begin{tabular}{|l|c|c|c|c|c|} 
Model Pembelajaran Konvensional (A2) & 76,455 & 73,75 & 68,333 & 73,25 & 72,947 \\
\hline Rataan Marginal & 78,173 & 75,025 & 77,167 & 77,813 & \multicolumn{1}{|c}{} \\
\cline { 1 - 5 }
\end{tabular}

Berdasarkan rata-rata pada tabel 7 memperlihatkan rata-rata kemampuan pemecahan masalah matematis siswa dengan model TGT menggunakan sandi semaphore pramuka lebih besar yakni 81,141 dari pada rata-rata kemampuan pemecahan masalah matematis siswa dengan model konvensional yakni sejumlah 72,947. Sesuai dengan pernyataan itu, bisa ditarik kesimpulan bahwasannya siswa dengan model TGT menggunakan sandi semaphore pramuka memperoleh nilai kemampuan pemecahan masalah matematis yang lebih baik dibandingkan dengan siswa yang mendapat perlakuan model pembelajaran konvensional.

\section{Pengaruh Model Pembelajaran Teams Games Tournament (TGT) Menggunakan Sandi Semaphore Pramuka Terhadap Kemampuan Pemecahan Masalah Matematis Siswa}

Berdasarkan hasil dari perhitungan anava dua jalan diperoleh $F_{\text {hitung }}$ sebesar 13,846 dan $F_{\text {tabel }}$ sebesar 4,010 sehingga diperoleh $F_{\text {hitung }}>F_{\text {tabel }}$ maka $\mathrm{H}_{0 \mathrm{~A}}$ ditolak. Kesimpulannya bahwa terdapat pengaruh model pembelajaran Teams Games Tournament (TGT) menggunakan sandi semaphore pramuka dan siswa pada kelas yang menggunakan model pembelajaran konvensional terhadap kemampuan pemecahan masalah matematis siswa. Hal tersebut diketahui dari nilai rata-rata Posttest siswa pada kelas yang menggunakan model pembelajaran Teams Games Tournament (TGT) menggunakan sandi semaphore pramuka lebih tinggi dibandingkan dengan siswa pada kelas yang menggunakan model pembelajaran konvensional. Berdasarkan nilai rata-rata Postest tersebut, disimpulkan bahwa model pembelajaran Teams Games Tournament (TGT) menggunakan sandi semaphore pramuka lebih baik dibandingkan model pembelajaran konvensional.

Kelas yang diberikan pembelajaran Teams Games Tournament (TGT) menggunakan sandi semaphore pramuka terlihat lebih aktif dan siswa lebih antusias dibandingkan pembelajaran konvensional. Hal ini terjadi karena pembelajaran dengan model pembelajaran Teams Games Tournament (TGT) menggunakan sandi semaphore pramuka lebih memberi kesempatan siswa untuk lebih antusias dan aktif, siswa mulai menumbuhkan rasa ingin tahu yang besar, apalagi siswa sangat tertarik dengan sandi semaphore pramuka karena baru kali ini pembelajaran matematika pada materi garis dan sudut di gabungkan dengan materi pramuka. Dalam proses pembelajaran menggunakan model pembelajaran Teams Games Tournament (TGT) sendiri terdapat sebuah permainan yang mengharuskan siswa menjawab pertanyaan-pertanyaan dari sandi semaphore pramuka, contohnya siswa diminta untuk menebak kata apa yang telah dibentuk dari sandi semaphore pramuka yang telah diperagakan oleh peneliti jika jawaban siswa benar selanjutnya siswa diminta untuk menentukan besar sudut masingmasing huruf pada kata yang terbentuk tersebut. Setelah itu siswa diminta menjelaskan huruf-huruf tersebut termasuk kedalam jenis sudut apa, sehingga siswa lebih semangat untuk memahami materi pelajaran selain itu siswa juga berlomba-lomba untuk menjawab pertanyaan yang diberikan oleh guru agar mendapatkan poin tambahan untuk kelompoknya. Selain itu siswa juga berlatih mengerjakan soal 
dalam bentuk pemecahan masalah yang dilakukan dalam diskusi kelompok. Kelas yang diberikan pembelajaran konvensional juga terlihat aktif namun kurang antusias karena dalam proses pembelajaran ini guru menjelaskan materi lalu siswa diberi latihan-latihan soal. hal tersebut mengakibatkan pembelajaran berlangsung seperti pembelajaran biasa.

Penelitian yang dilakukan peneliti ini juga dapat diketahui bahwa model pembelajaran Teams Games Tournament (TGT) menggunakan sandi semaphore pramuka memberikan $F_{\text {hitung }}>F_{\text {tabel }}$ yaitu 13,846>4,010 sehingga $\mathrm{H}_{0}$ ditolak dengan demikian dapat disimpulkan bahwa terdapat pengaruh model pembelajaran Teams Games Tournament (TGT) menggunakan sandi semaphore pramuka terhadap kemampuan pemecahan masalah matematis siswa.

Hasil penelitian sejalan dengan penelitian terdahulu yaitu oleh Sartika dengan judul "Pengaruh Model Pembelajaran TGT Terhadap Kemampuan Pemecahan Masalah Matematika Siswa Kelas VIII Semester Genap SMP Negeri 19 Bandar Lampung Tahun Pelajaran 2018/2019” (Sartika, 2018). Hasil penelitian ini adalah model pembelajaran Teams Games Tournament (TGT) memperoleh rata-rata kemampuan pemecahan masalah matematika yang lebih tinggi dari rata-rata kemampuan pemecahan masalah matematika siswa yang menggunakan model pembelajaran konvensional.Berdasarkan hal tersebut dapat membuktikan bahwa pembelajaran menggunakan Teams Games Tournament (TGT) menggunakan sandi semaphore pramuka dapat berpengaruh positif terhadap kemampuan pemecahan masalah matematis siswa kelas VII SMP Al-Huda Jati Agung.

\section{Perbedaan Efek Tipe Kepribadian Guardian, Artisan, Rational, Dan Idealist Siswa Terhadap Kemampuan Pemecahan Masalah Matematis Siswa}

Hasil perhitungan anava dua arah memperlihatkan tidak ada perbedaan efek tipe kepribadian Idealist, Rational, Artisan, dan Guardian siswa pada kemampuan pemecahan masalah matematik siswa. Hasil analisisnya menunjukkan bahwa nilai signifikansi antara kemampuan pemecahan masalah matematis siswa yang bertipe kepribadian itu ialah tidak terdapat perbedaan di antaranya ataupun sama. Tipe kepribaduan yang terdapat pada tiap-tiap siswa paa aktivitas belajar menagajr matematika nyatanya tidak berpengaruh pada hasil post test. Penulis membentuk kelompok dengan cara beragam heterogen ketika penelitian dilakukan. Sebelumnya siswa diberikan angket dulu agar memahami jenis kepribadian tiap-tiap siswa, kuesioner tersebut telah dinyatakan valid. Kueosioner jenis kepribadian tersebut mencakup 60 pernyataan yang dibentuk dosen psikologi UGM tahun 2004-2009 yakni, Nafisah Mudrika (Astuti, 2020). Sesudah angketnya dibagi ke siswa lalu diisikan berdasarkan dirinya, lalu dengan berisikan jawaban siswa dimasukkan ke dalam pengukuran melalui aplikasi Excel, dan jenis kepribadian tiap-tiap siswa ditetapkan sesuai dengan kuesioner yang telah diisi.

Penulis memberi latihan soal yang wajib diselesaikan siswa dengan cara kelompok. Dalam segi teoritis, siswa yang berkepribadian guardian tidak begitu aktif saat berkelompok, namun cenderung menyukai kegiatan tanya jawab, dan memprioritaskan materi cerita (kata-kata) daripada yang berupa gambar visual. Siswa yang bertipe artisan aktif pada saat berdiskusi secara berkelompok sebab sangat suka terhadap berdiskusi dan kerja kelompok. Siswa yang bertipe rational tidak begitu aktif saat 
Pengaruh Model Pembelajaran Teams Games Tournament Menggunakan Sandi Semaphore Pramuka Terhadap Kemampuan Pemecahan Masalah Matematis Ditinjau dari Tipe Kepribadian Siswa, Siti Nurfajriah, Netriwati, Rany Widyastuti

berdiskusi, lebih menyukai sesuatu yang contohnya eksplorasi ataupun eksperimen. Siswa bertipe idealist tidak suka diskusi ataupun bekerja kelompok, sebab bersifat kreatif dan mandiri.

Hasil penelitian memperlihatkan bahwasannya tidak terdapat perbedaan yang signifikan terhadap siswa yang bertipe kepribadian idealist, rational, artisan, dan guardian, dan. Hal tersebut tidak selaras terhadap teori bahwasannya tipe kepribadian bisa berpengaruh terhadap prestasi akademik siswa. Tidak selarasnya terhadap hasil penelitian pada teori bisa dikarenakan saat mengisi kueosioner tidak serius dan tidak selaras terhadap kepribadian yang dimiliki karena siswa cukup kesulitan utnuk mengerti karakternya sendiri dan siswa masih berada di bangku SMP.

Sesuai dengan hasil penelitiannya, bisa ditarik kesimpulan bahwasannya siswa yang bertipe kepribadian idealist, rational, artisan, dan guardian tidak mempunyai perbedaan rata-rata kemampuan pemecahan masalah matematik terhadap siswa dan model Teams Games Tournament (TGT) dengan siswa yang menggunakan model pembelajaran konvensional.

Hasil penelitian sejalan dengan penelitian yang dilakukan oleh Nis Maya dengan judul "Analisis Tipe Kepribadian Siswa dan Pengaruhnya Terhadap Kemampuan Pemecahan Masalah Matematika Menggunakan Model Problem Based Learning" (Maya, 2018). Hasil penelitiannya memperlihatkan bahwasannya tidak ada perbedaan terhadap kemampuan pemecahan masalah matematis melalui model $P B L$, model PBL dengan asesmen kinerja ditinjau dari tipe kepribadian (guardian, artisan, rational dan idealist).

\section{Interaksi Antara Model Pembelajaran dan Tipe Kepribadian Siswa Terhadap Kemampuan Pemecahan Masalah Matematis}

Interaksi pada penelitian ini yakni tipe kepribadian dan model pembelajaran pada kemampuan pemecahan masalah matematis. Sesuai perhitungan anava dua arah bahwa tidak terdapat hubungan terhadap tipe kepribadian siswa dan model pembelajaran pada kemampuan pemecahan masalah matematik. Model pembelajaran yang dipakai yakni Teams Games Tournament (TGT) menggunakan sandi semaphore pramuka dan model pembelajaran konvensional.

Dalam segi teoritis, sesuatu yang bisa berpengaruh terhadap kemampuan pemecahan masalah matemats yakni cara guru menerangkan materi dan mengaitkan kegiatan belajar pada pemecahan masalah dalam bentuk ungkapan matematik, gambar, kata-kata, ataupun simbol. Model Teams Games Tournament (TGT) menggunakan sandi semaphore pramuka sangat sesuai terhadap peningkatan kemampuan pemecahan masalah matematik melalui penyelesaian permasalahan yang bisa dipecahkan siswa dalam pada sejumlah cara matematisnya.

Hasil penelitian yang dilaksanakan selaras terhadap penelitian Fera Yuriza Yanti yang berjudul "Pengaruh Pembelajaran Kooperatif Tipe CO-OP CO-OP Berbasis Open Ended Terhadap Kemampuan Pemecahan Masalah Matematis Ditinjau Dari Tipe Kepribadian Peserta Didik SMP Negeri 3 Bandar Lampung Tahun Ajaran 2019/2020" (Yanti, 2018). Hasil penelitian menunjukan tidak ada interaksi terhadap tipe kepribadian siswa dan model pembelajaran pada kemampuan pemecahan masalah matematis siswa. Hasil yang tidak sesuai tersebut mungkin dikarenakan ada sejumlah siswa yang 
menyelesaikan soal dengan melakukan kerja sama pada siswa yang lain sehingga informasi dalam mengerjakan soal tersebut tidak akurat dan siswa dalam pengisian angketnya tidak berdasarkan kepribadiannya dengan demikian berpengaruh pada ketidaksesuaian hasilnya terhadap teori.

\section{KESIMPULAN}

Berdasarkan hasil penelitian yang telah dilakukan dapat ditarik kesimpulan bahwa: (1) terdapat pengaruh model pembelajaran TGT (Teams Games Tournament) menggunakan sandi semaphore pramuka terhadap kemampuan pemecahan masalah matematis siswa. Siswa yang diberikan perlakuan pembelajaran dengan model pembelajaran Teams Games Turament menggunakan sandi semaphore pramuka memiliki kemampuan pemecahan masalah yang lebih baik dibandingkan dengan siswa yang diberikan perlakuan dengan model pembelajaran konvensional, (2) tidak terdapat pengaruh tipe kepribadian siswa terhadap kemampuan pemecahan masalah matematis siswa. Hal tersebut tidak selaras terhadap teori bahwasannya tipe kepribadian bisa berpengaruh terhadap prestasi akademik siswa. Tidak selarasnya terhadap hasil penelitian pada teori bisa dikarenakan saat mengisi kueosioner siswa tidak serius dan tidak selaras dengan kepribadian yang dimiliki karena siswa cukup kesulitan untuk mengerti karakternya sendiri dan siswa masih berada di bangku SMP, dan (3) tidak terdapat interaksi antara model pembelajaran dengan tipe kepribadian siswa terhadap kemampuan pemecahan masalah matematis siswa. Hasil yang tidak sesuai tersebut dikarenakan ada sejumlah siswa yang menyelesaikan soal dengan melakukan kerja sama dengan siswa yang lain sehingga informasi dalam mengerjakan soal tersebut tidak akurat dan siswa dalam pengisian angketnya tidak berdasarkan kepribadiannya dengan demikian berpengaruh pada ketidaksesuaian hasilnya terhadap teori.

\section{UCAPAN TERIMA KASIH}

Peneliti mengucapkan rasa syukur kepada Allah SWT karena selalu diberikan kelancaran dalam menyelesaikan artikel ini. Peneliti juga mengucapkan terima kasih kepada orangtua dan keluarga yang telah memberi dukungan penuh kepada peneliti. Rasa terima kasih juga peneliti ucapkan kepada pembimbing saya yakni Ibu Netriwati, M.Pd. dan Ibu Rany Widyastuti, M.Pd. yang telah memberikan bimbingan dan arahan dalam menyelesaikan penelitian dan artikel ini. Terakhir, rasa terima kasih ini peneliti ucapkan kepada sahabat-sahabat saya yang selalu memberi dukungan dan semangat.

\section{REFERENSI}

Astuti, W. A. (2020). Metode Myer Briggs Type Indicator (Mbti) Untuk Tes Kepribadian Sebagai Media Pengembangan Diri (Studi Kasus; SMA N 2 Kebumen). Jurnal Of Information System Management.

Delima, I. (2019). Pengaruh Model Pembelajaran Tgt (Teams Games Tournament) Modifikasi Metode Gasing Terhadap Kemampuan Pemecahan Masalah Matematis Peserta Didik Kelas Vii Smp Negeri 36 Bandar Lampung. Universitas Islam Negeri Raden Intan Lampung. 
Pengaruh Model Pembelajaran Teams Games Tournament Menggunakan Sandi Semaphore Pramuka Terhadap Kemampuan Pemecahan Masalah Matematis Ditinjau dari Tipe Kepribadian Siswa, Siti Nurfajriah, Netriwati, Rany Widyastuti

Dian Safitri, M. A. (2020). Pengaruh Model Kooperatif Tipe Teams Games Tournament (TGT) Terhadap Kemampuan Pemecahan Masalah Matematika Dan Self Efficacy Siswa. Jurnal Penelitian Matematika Dan Pendidikan Matematika.

Iswati, M. A. (2017). Metode Penelitian Kuantitatif. Surabaya: Airlangga University Press.

Kementerian Pendidikan Dan Kebudayaan, P. M. (2006). Standar Isi Untuk Satuan Pendidikan Dasar Dan Menengah.

Maya, N. (2018). Analisis Tipe Kepribadian Siswa Dan Pengaruhnyaterhadap Kemampuan Pemecahan Masalahmatematika Menggunakan Modelproblem Based Learning. Pasundan Journal of Research In Mathematics Learning And Education.

Nurjanah, E. (2019). Metodologi Pendidikan Islam. Bandung: Alfabeta Publisher.

Sahriai, U. M. (2021). Deskripsi Kemampuan Pemecahan Masalah Matematika Siswa Ditinjau Dari Tipe Kepribadian Menurut Keirsey. Journal Issues In Mathematics Education.

Sartika. (2018). Pengaruh Model Pembelajaran Tgt Terhadap Kemampuan Pemecahan Masalah Matematika Siswa Kelas Viii Semester Genap SMP Negeri 19 Bandar Lampung Tahun Pelajaran 2018/2019. Jurnal Ilmiah Mahasiswa Pendidikan Matematika Stkip Pgri Bandar Lampung.

Siregar, S. (2019). Statistik Parametrik Untuk Penelitian Kuantitatif. Jakarta: Pt Bumi Aksar.

Sunardi, A. B. (2016). Boy Man Ragam Latih Pramuka Cetakan Kesepuluh. Bandung: Darma Utama.

Yanti, F. Y. (2018). Pengaruh Pembelajaran Kooperatif Tipe Co-Op Co-Opberbasis Open Ended Terhadap Kemampuan Pemecahanmasalah Matematis Ditinjau Dari Tipe Kepribadianpeserta Didik Smp. Skripsii Universitas Islam Negeri Raden Intan. 